Preprint of an article published in The Australian Surveyor, December 1987, Vol. 33 No. 8

\title{
LESSONS FROM THE SWEDISH LAND DATA BANK SYSTEM
}

I. P. Williamson, PhD(NSW), MAIC, MIS(Aust), LS,

Professor of Surveying and Chairman,

Department of Surveying,

University of Melbourne.

\section{ABSTRACT}

In 1985 the Victorian Government contracted consultants from the Swedish Central Board for Real Estate Data to assist in a study into the development of the Victorian land information system (LIS) with emphasis on the development and role of an automated land titles system within the LIS. This paper suggests it is beneficial for Victoria to have a broad understanding of the Swedish system in order to put any recommendations in perspective. As a consequence the paper reviews the Swedish cadastral and land information system, and highlights lessons and issues derived from the Swedish system which may benefit the development of land information systems in Victoria as well as other jurisdictions in Australia.

\section{INTRODUCTION}

In 1985 the Victorian Government contracted consultants from the Swedish Central Board for Real Estate Data to assist in a study concerned with the joint interests of LANDATA (the Victorian Government's land information unit) and the Titles Office. The report of that study was submitted to the Victorian Government in March 1985 (Victorian Government, 1985). The primary objective of the study was to determine the role of the Titles Office within the state's land information strategy.

The specific problems in Victoria concerning parcel based data in this regard are:

1. the duplication in processing notices of disposition of interests in land,

2. the duplication of cadastral mapping activities,

3. data exchange between organisations,

The broad objectives of LANDATA are:

1. reduce duplication and incompatibilities between systems using land related data,

2. increase government efficiency in land administration,

3. develop new land information products and services.

As a consequence of the involvement of Sweden in Victoria the author considered it would be of interest to review the Swedish cadastral surveying and mapping, land registration and land information system to see what the system has to offer Victoria and other Australian states in general; this paper is the result.

There are similarities in the Swedish and Victorian systems, particularly since they both use registration of titles, however the differences are more than the similarities. One of the biggest differences is that the Swedish cadastral system is decentralised and interestingly through computerisation is becoming increasingly centralised; the opposite is the objective for Victoria, although the end result of each system is somewhat similar. In addition the Swedish cadastral system is "map based" whereas the Victorian system is primarily based on individual parcel surveys. Of interest the terms cadastral and cadastre are unheard of in Sweden since the Swedish system was not patterned on the Napoleonic cadastres, albeit they have much in common. In Sweden the term "property formation" equates to "cadastral survey" and 
"property registration" equates to "title registration".

However maybe the biggest difference is that the Swedish bureaucracy and society appears much more organised and structured than Victorian society.

In order to achieve the aim of the paper, a brief review is made of institutional arrangements in Sweden for land administration and the operation of Sweden's land information system (or Land Data Bank). The paper then concentrates on lessons which may be of interest from a study of the Swedish system.

\section{INSTITUTIONAL ARRANGEMENTS}

Sweden has an area of about $450,000 \mathrm{~km} 2$ (Victoria 227,600 km2), a population of 8.3 million (Victoria 4.5 million), about 4 million land parcels (Victoria about 2 million) of which approximately half are in the Swedish Land Data Bank System.

The basic institutional arrangements in the Swedish land information system are shown in Figure 1 (Central Board of Real Estate Data, 1985). The National Court Administration within the Ministry of Justice administers all conveyancing and property transactions through its 95 Land Register Agencies. This organisation is the title registration authority. It maintains the

originals of all transfers, mortgages, etc. and copies of all titles in the register books in areas not computerised. In areas which have been computerised, the agencies have terminals into the central computer within the Central Board for Real Estate Data (CFD) where the computerised titles are held. The Land Register Agencies record the legal interests in land which comprises the majority of the information in the Land Data Bank System.

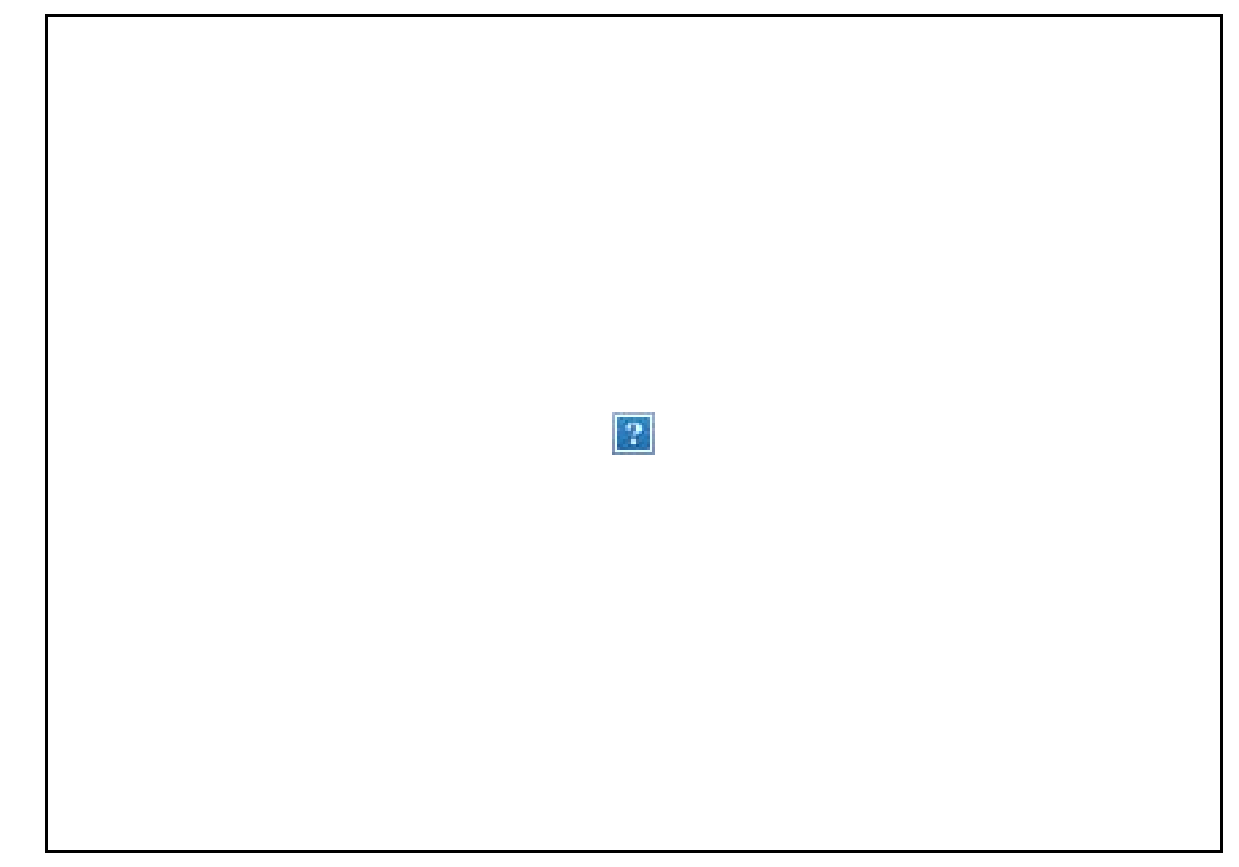

The spatial or map component of the system is administered through 55 Real Property Register Agencies which are completely separate entities from the Land Register Agencies. The agencies are administered by the National Land Survey within the Ministry of Housing and Physical Planning. The Real Property Register Agencies control the subdivision of land and maintain a register of all properties or legal land parcels in the country for purposes of title registration, land taxation, land surveying, statistics, population registration, and urban and regional planning.

The Land Data Bank System which handles the textual data for title registration and parcel information is maintained by the Central Board for Real Estate Data also within the Ministry of Housing and Physical 
Planning.

Another important component of the system is land taxation which is administered by the Central Land Tax Board within the Ministry of Finance through 100 local taxation authorities. The Land Tax board updates basic valuation data in the CFD annually. The Board of Directors of the CFD comprises the heads of all the major organisations involved with parcel data.

The CFD comprises seven divisions as follows:

1. Property Registration - responsible for information about land parcels, area, unique identifiers, addresses, etc.

2. Land Registration - responsible for ownership details, transfers, leases. mortgages etc.

3. Technical - responsible for EDP development.

4. Administration

5. Computing Centre

6. Planning Unit - responsible for strategic and corporate planning.

7. Development Unit - responsible for new products.

The CFD has a staff of over 150 persons, with over $50 \%$ being professional land surveyors, engineers, lawyers, system analysts, EDP specialists, planners and economists.

\section{THE SWEDISH LAND INFORMATION SYSTEM}

\section{Land Registration}

All land transactions are administered by the decentralised Land Register Agencies as part of the title registration system which was established in 1875. Prior to this a deeds registration system operated. In the non-computerised system, title details are kept in Register Books which record all the title information. Title goes to a "property" which may contain many physically separated "parcels". Title to individual parcels is not possible without an official subdivision.

Today approximately half of all titles of properties are fully computerised ( 2 million titles). The first computer folio was created in 1976. There are about 2 million dealings in Sweden each year. With the computerised system, transfers or dealings are registered within one or two days. Within Sweden prescription is permitted with a statutory period of 20 years however it doesn't occur very often due to the complete parcel mapping system.

\section{Property Surveying and Mapping}

The Real Property Register Agencies keep the cadastral maps and the associated property (and parcel) registers up-to-date. In rural areas, the cadastral framework is maintained on a 1:10,000 map series (see Figure 2 - Courtesy National Land Survey) and in urban areas on a 1:1,000 map series (see Figure 3 Courtesy National Land Survey).

In city areas the local municipality usually maintains a 1:500 map series which is used as a base for all utility and other municipal services. The 1:10,000 rural map is termed the Economic Map Series for the country and consists of a cadastral overlay onto an orthophoto base. Boundaries plotted on this map can be scaled to +2 metres.

In rural areas a graphic cadastre is used based on the 1:10,000 map series, although in some cases rural surveys are coordinated. In urban areas, all surveys are coordinated on the National Coordinate System. In defining boundaries most weight appears to be given to the map, next the boundary markers and lastly to occupations, while recognising that prescription is possible in Sweden. The regulations for property surveys are very broad. Methods are left to the surveyor and the only criteria is that the end result is 
acceptable and the accuracy standards are met.

There are specific regulations for First, Second and Third order control surveys, photogrammetric surveys and cadastral surveys. Cadastral or property surveys have four measurement classes as follows:

Class One areas with particularly high demands on accuracy for construction etc

Class Two densely populated urban areas with high land values

Class Three other urban or rural areas with relatively high land values

Class Four rural areas and areas of low land value

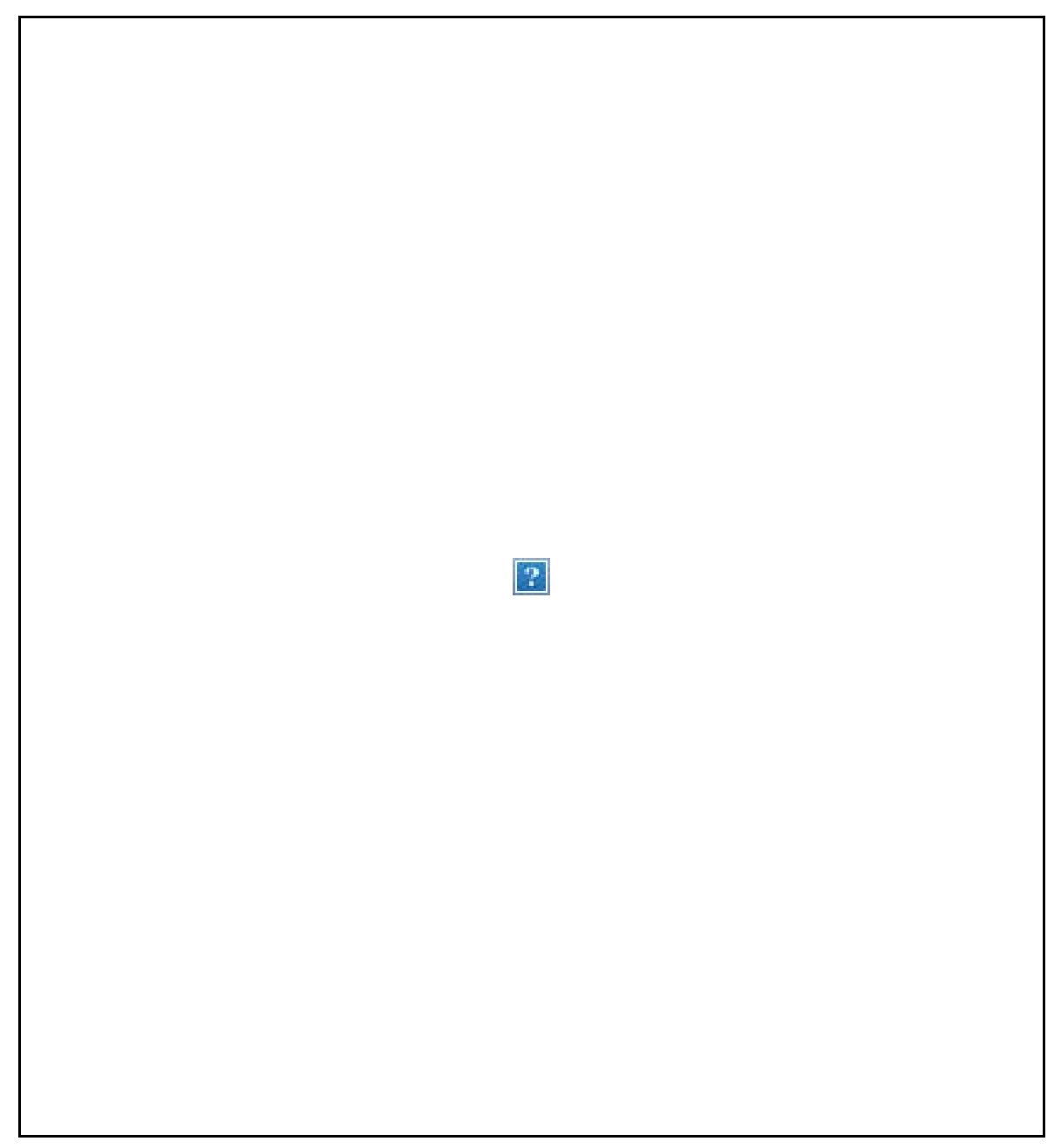




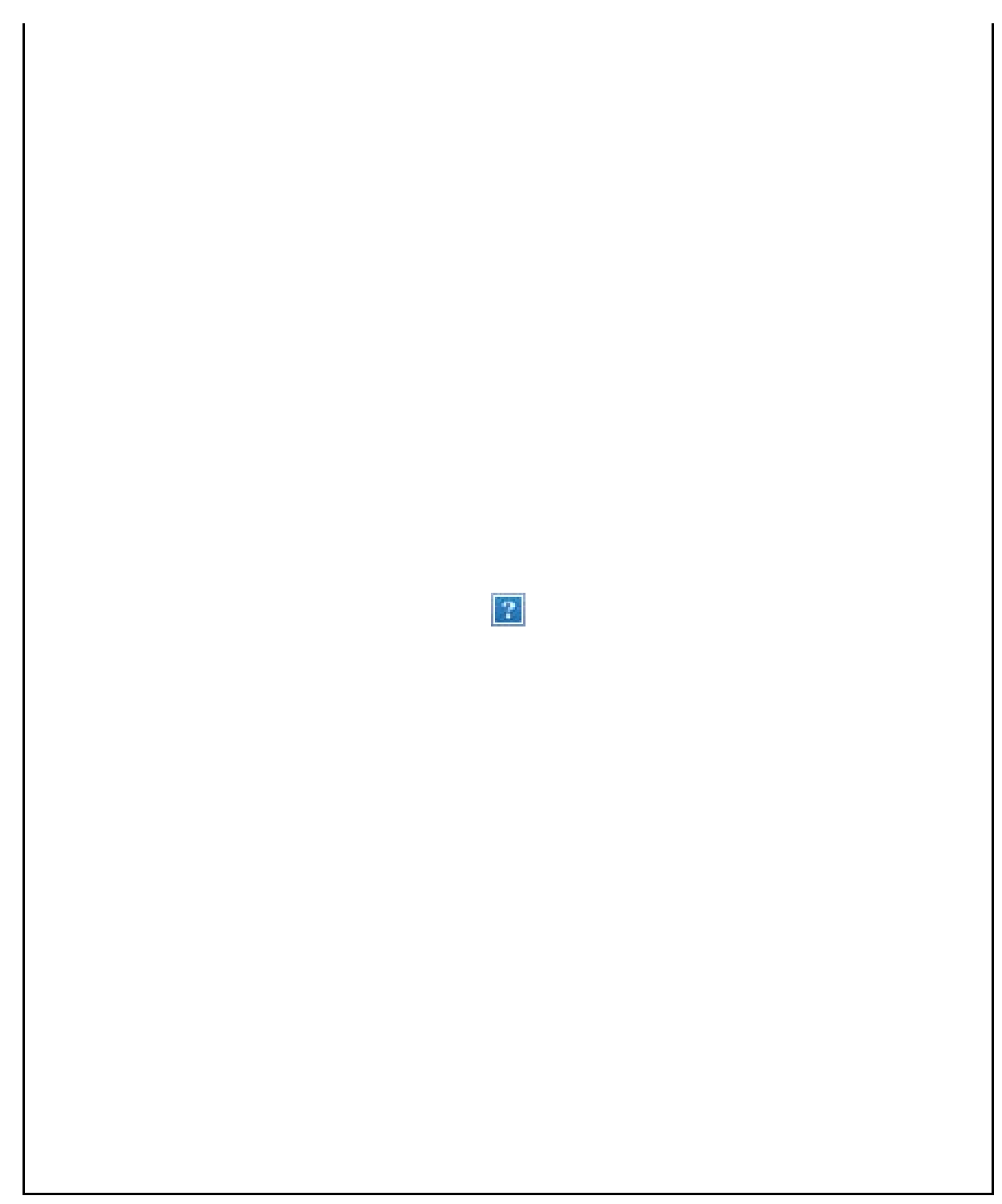

For example in a regional city in suburban areas (Class Three) the following accuracy criteria apply:

\section{Traverse closure between two coordinated control points}

1. Difference between two measurements of the length of a traverse side.

Allowable difference $=(0.0025 \mathrm{~L}+0.01)$ metres

where $\mathrm{L}$ is the length of the side in metres

For example for a distance of $100 \mathrm{~m}$ the difference should be less than $0.035 \mathrm{~m}$.

2. Angular closure in a traverse.

Allowable closure $=0.007$ grads

where $\mathrm{n}$ equals the number of occupied stations (centecimal division of circle)

For example for a traverse with six occupied stations the closure should be better than 0.017 grads or 55 seconds.

3. Point closure error (see original paper in The Australian Surveyor) 
Allowable error

Where $f_{x}=$ closing error in $x$ - coordinate and $f_{y}=$ closing error in $y$ - coordinate. $f_{e}=0.006$ Ö L metres, where $L=$ sum of length of sides of treverse in metres. For example for a traverse of $500 \mathrm{~m}$ the point closure error should be less than $0.134 \mathrm{~m}$

\section{Detailed measurement}

For example the distance between two boundary points or building corners.

Allowable error $=0.06+0.0004 \mathrm{~L}$ metres, where $\mathrm{L}=$ distance between measured points in metres

If $\mathrm{L}=0$, the limit is used for two determinations of the same point.

For example the allowable error between two boundary marks $50 \mathrm{~m}$ apart would be $0.08 \mathrm{~m}$.

No cadastral surveys are done by private surveyors in Sweden. The National Land Survey (NLS) does $80 \%$ of all such surveys, municipalities undertaking the remainder. The NLS competes against the private sector on all other forms of survey such as small topographic surveys and building setouts. The NLS is responsible for all topographic maps for both civilian and military uses, aeronautical charts, economic maps, national digital terrain models, the Geodetic Survey of Sweden, forestry maps, urban maps, property registers and undertakes valuation of properties for the Central Land Tax Board.

\section{Valuation}

The Central Land Tax Board maintains a detailed computerised valuation system as part of the Land Tax Register. Land taxation commenced in Sweden in 1540 with the first valuation maps being prepared in 1600. These maps have subsequently developed into the

present cadastral map series. The NLS is one of the largest land appraisers for the Central Land Tax Board. The NLS systematically updates the Board's data base of sales (sales are added monthly to the NLS data base). The Land Tax Board updates the CFD data base with basic valuation data annually.

A key component in valuation in Sweden is the preparation of Land Value Maps. These maps show average values for sections or blocks of land and different types of buildings. Each map is accompanied by a set of tables. The Land Value Maps differ depending on the type of real estate and the locality. The maps are prepared on the basis of current sale prices.

\section{Population Register}

Statistics Sweden maintains a Population Register where persons are related to the property (and address). It is a requirement of law to inform the government of a change in address. Changes in address are given weekly to the CFD by Statistics Sweden. Since the CFD has the centroid (in the National Coordinate system) of each parcel, the spatial distribution of the population at the parcel level can be easily determined. This ability is used extensively in Sweden for planning purposes.

\section{Land Data Bank System}

The core of the the Swedish land information system is the Land Data Bank maintained by the Central Board for Real Estate Data (CFD). A schematic of the system is shown in Figure 4. (Central Board for 
Real Estate Data, 1985).

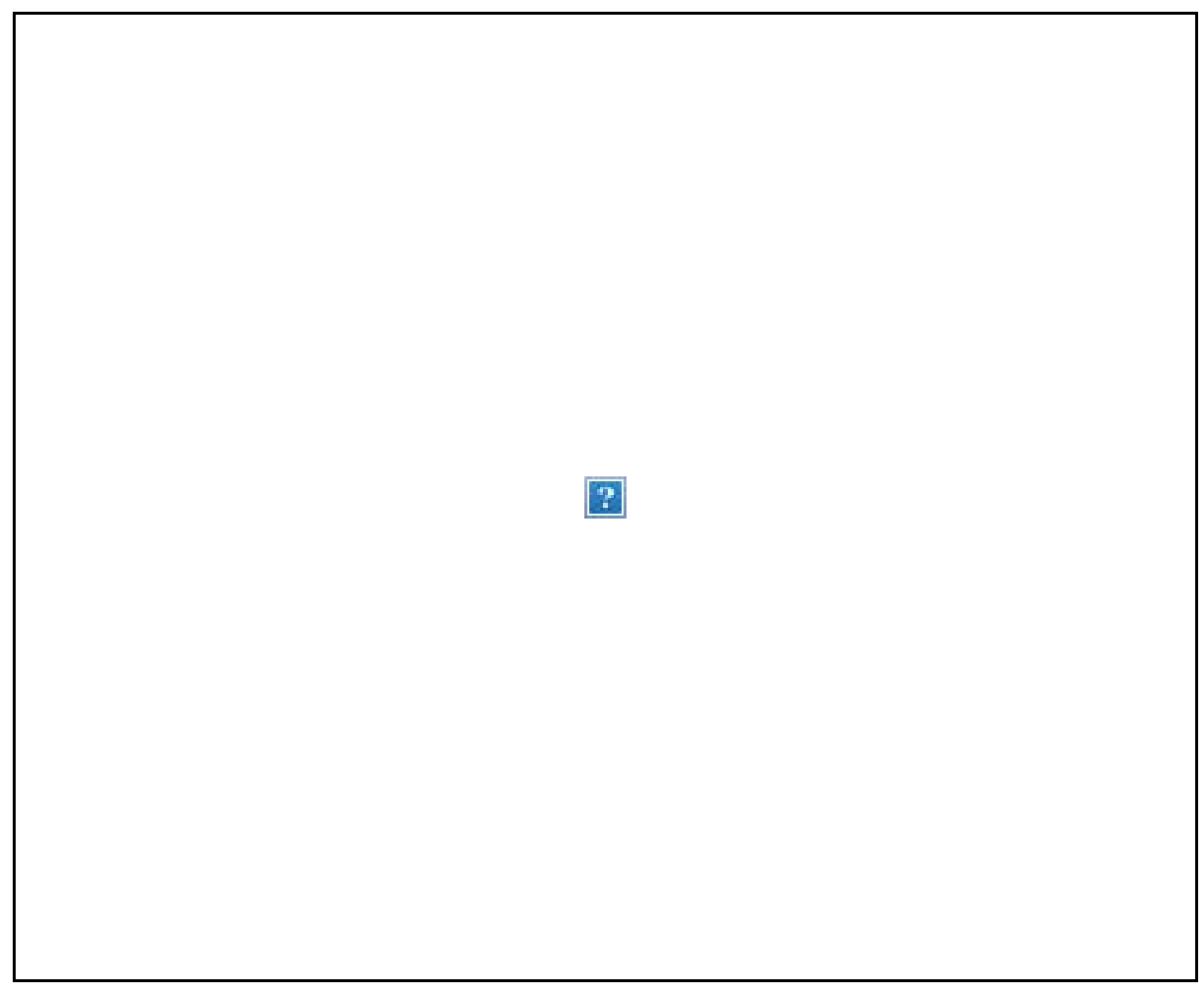

\section{Schematic of the Swedish Land Data Bank.}

Figure 4.

The information contained on each real property unit is shown in Figure 5 (Central Board for Real Estate Data,1985.) The costs for development/maintenance and loading of data bases (basic data conversion) is about $0.02 \%$ of each property's value. The cost of additional data such as coordinate centroid, map references, assessed value and address is about $0.01 \%$ of each property's value.

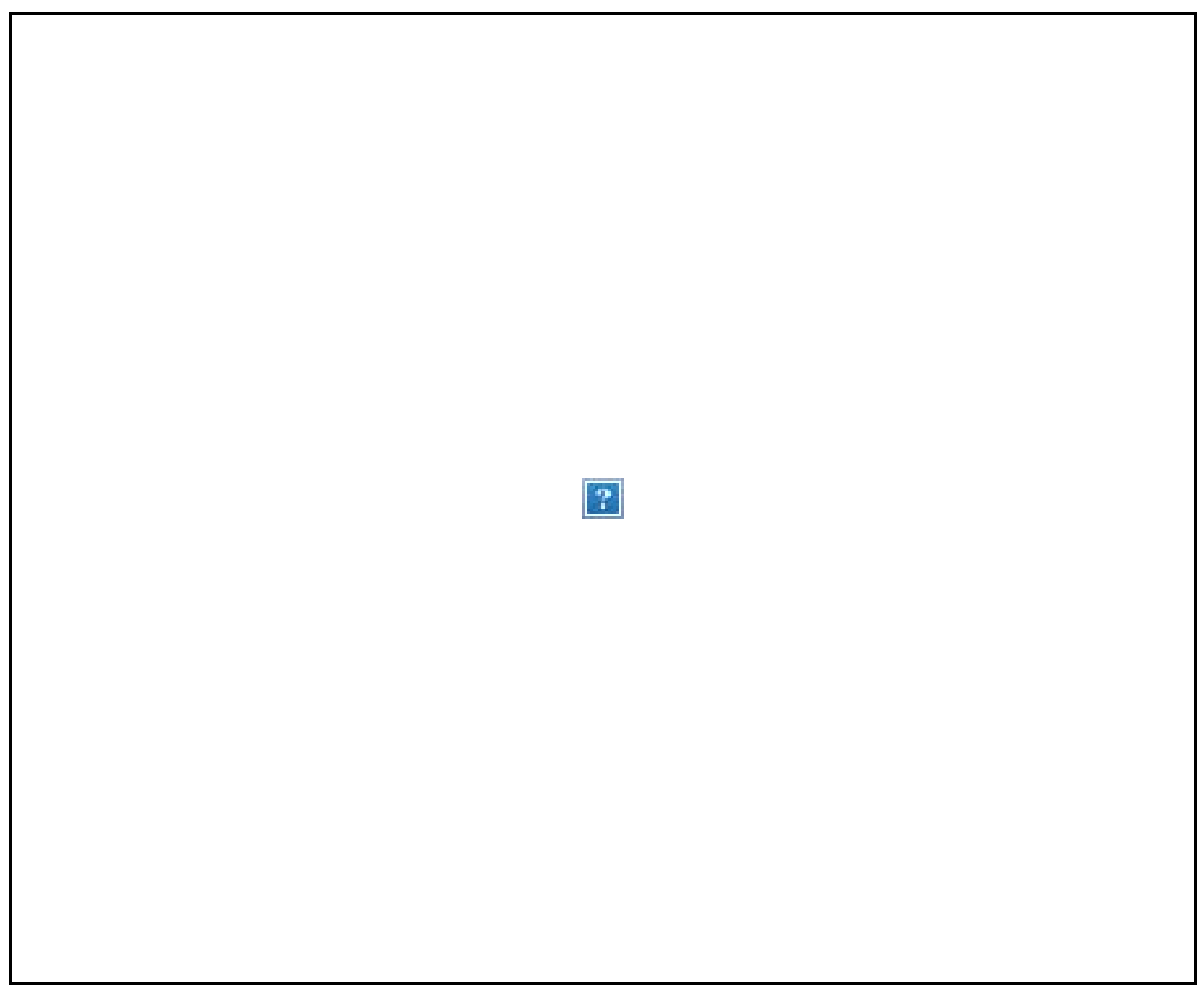




\section{Information recorded for each property unit in the Land Data Bank}

\section{Figure 5}

There are about 200 characters registered for each real property. All data in the system concerned with title registration is "guaranteed" in a similar manner to that in the Torrens System according to the Swedish Act on Automatic Land Title Registration (SFS 1973:98).

The system only contains textual data although the coordinates of the visual centroid of all properties, houses and historic monuments are recorded and updated regularly.

Sweden places considerable emphasis on the accessibility of the data in the system. The two most common methods of acessing the data base are via a telephone communication system called DATEL and VIDEOTEX. As of September 1986 there were 510 terminals using DATEL in Land Register Agencies, Real Property Register Agencies, banks, land brokers and municipalities. At present there are 400 subscribers on VIDEOTEX with an anticipated 2000 by 1987. For more details on the system, reference should be made to Central Board for Real Estate Data, (1985) and Anderson, (1986).

\section{LESSONS}

The following is a list of lessons on matters of interest that are of value from a study of the Swedish system which may have of relevance in the development of computerised parcel-based land information systems in Australia.

1. Sweden did not undertake major institutional change in order to develop a national parcel based land information system. The only addition to the bureaucracy was the creation of the CFD in the Ministry of Housing and Physical Planning. Of interest the survey organisation (National Land Survey) and the title organisation (National Court Administration) were not combined nor changed from their historical ministries.

2. The land tax and valuation data bases are kept separately from the CFD. Once a year information from these data bases, which is relevant to the CFD, is transferred.

3. The Swedish land information system was not created quickly. The first decision to establish it was made in 1973. It was not until 1985 that the Swedish Parliament confirmed the future of the system. It therefore took 12 years to obtain the full "go-ahead". Anticipated completion of the system is in 1992 (19 years after commencement to put 3.5 million properties in the system).

4. The creation of the Swedish LIS was based on an extenisive pilot study in one county. The system is now being introduced area by area in an incremental manner.

5. The major benefit of the system is that it saves the government money! The major benefits of the system are:

- $50 \%$ reduction in land registry personnel

- savings in office space

- the period for registration has been reduced from

- one month to two days

- the system generates income for the government

- the system permits new products to be created from the data base.

6. Sweden did not change the existing parcel identification system even though the present system is complex by modern standards. An interesting lesson regarding parcel identifidation is explained by Osterberg (1987):

"The procedure to automate a country always starts with an overview of the parcel identification system. The old records are based on parishes (about 3000) and the automated system on municipalities (about 3000). This means that many villages and areas with similar 
names in principle have to be renamed before entering the computer system. Today computer people do nor consider this renaming necessary from the point of EDP, but the fact is tha in 1968 it was considered necessary from EDP point of view to do this renaming.

The change form parish to municipality as the basic registration area was perhaps the greatest mistake at the beginning. This renaming created local opposition and resistance in Parliament which delayed decisions for several years. This delay was critical because in the meantime costs rose and new technical solutions became available at the market which created more questioning and new investigation by the Parliament.

Today this renaming is done rather free of conflicts by adding a code for the parish to names that are similar in a municipality. This code is invisible to the user."

7. Data for the system is collected at its source through decentralised offices. Data is stored and managed at a central location. Some thought is now being given to regionalisation of the data base. The data base is accessed through a network of terminals spread across Sweden.

8. All land in the areas covered by the system are in the data base, including roads, without exception. It must be recognised that Sweden has had a history of an organised approach to cadastral mapping and parcel identification since the 16 th century.

9. Sweden can do a considerable amount of socio-economic analyses using the parcel centroid/address/person data and also because the CFD holds the latest census data at the parcel level (note: information derived from census data can only be made public by the CFD if it is an aggregation of two or more parcels).

10. It has been beneficial for the CFD to run the system for about 2 million properties on one central computer, however as the system expands in the future it may create regional computer centres.

11. An automated land title system is an integral component of the central data base. In general the system records only current data. Automated land titles do not present a problem legally; a simple new (short) statute was introduced.

12. The CFD is run by an Interdepartmental Steering Committee which is constituted as a Board of Directors.

13. The system is surprisingly simple with regard to the data maintained in the data base. There is no graphic data in the system other than the coordinate centroid of parcels. The graphic component in the system is maintained as hard copy maps by the National Land Survey. Only the latent property valuation is contained in the system. Other valuation data is maintained on the separate valuation data base. There are two main sets of data for each property in the system, namely the parcel description and the legal interests. The system recognises the importance of maintaining only primary source data.

14. Within the Swedish system, cadastral surveys are only a tool. The cadastral maps are the basic spatial component in the system.

15. Experience has shown that as soon as the data process collection is operational, data collection productivity is more than planned.

16. The CFD recognises the importance of collecting data at the source. As a consequence links are being made between the CFD and local government (municipalities) whereby municipal records will be updated nightly. In addition, since municipalities approve all buildings and structures on land and update their own map bases with this building data, the CFD is considering establishing a Buildings Register in the CFD which will be updated by the municipalities.

17. The creation of a simple textual parcel-based component of a national land information system is a large, complex task. The CFD, for example, which only maintains the central data base and is independent of the property mapping and land registration functions, contains over 150 people of which over $50 \%$ are professionals. The system design has required over 100 man years of effort.

18. Even after 12 years the CFD is still in a major developement phase, where development and some research are allocated approximately $10 \%$ of the annual budget.

19. The system is not interactive but uses batch processing at night. Transactions are sent by telephone.

20. Digitisation of cadastral or property maps is commencing in urban areas in Sweden. 
21. Thirty years ago the Swedish system of education for surveyors was similar to Australia with the primary emphasis being on measurement science. Today the emphasis is about $50 \%$ on measurement science and $50 \%$ on land economics/land valuation/land administration.

\section{CONCLUSION}

By asking Sweden to participate in a review of land titles and LIS in Victoria shows a maturity and perspective in land administration in Australia that was not evident in this country ten years ago. Particularly in the 1950's to 1970's there was a belief in some quarters in Australia that our cadastral survey system and Torrens system of title registration was "par execellence", and that we had little to learn in the cadastral area from other countries. Fortunately this view has changed. There is now a recognition that cadastral systems are dynamic and that none are perfect. Victoria can learn from other systems even though it is already in many areas a highly sophisticated system and considering current initiatives in the state, has the potential to be at the forefront of cadastral and LIS developments. Of interest the South Australian Government has also recognised the benefits of gaining the advice of overseas governments with the involvement of Canada in a study into a coordinated cadastre for South Australia.

In getting another country to come and give advice in the cadastral/LIS area, it is valuable to have some understanding of that country's system in order to put their advice in perspective; this is the objective of this paper. This is particularly the case with a jurisdiction such as Victoria which has much to learn from Sweden in some areas, but in other areas is more advanced than Sweden.

This brief review of Sweden again highlights the fact that all cadastral/LIS systems are different and operate in different social, economic, institutional and legal environments. The review shows that some of the "accepted principles" for the establishment of LIS in Australia are not mandatory. However, overall there is considerable benefit in getting a country such as Sweden to participate in a cadastral/LIS review particularly when the review highlights automated land titles, an area where Sweden has considerable experience.

\section{REFERENCES}

Victorian Government, 1985. "The LANDATA/Titles Office Interface - A report to the LANDATA Executive Committee" Department of Property and Services, Melbourne.

Central Board for Real Estate Data, 1985. "The Swedish Land Data Bank System - a Land Information System for the basic registration and use of real property and land information".

Gravle, Sweden. (Official Publication)

Andersson, S. 1986 "The Swedish Land Data Bank." Proceedings of Auto Carto London, Volume 2, 122 128. 14 - 19 September, 1986. London.

\section{ACKNOWLEDGEMENT}

The author gratefully acknowledges the assistance of the staff of the Swedish Central Board of Real Estate Data and the Swedish National Land Survey in the preparation of this article. In particular thanks are due to the Director of the Central Board of Real Estate Data, Mr Sune Andersson and the Head of the Division of Cadastral Surveys, National Land Survey, Mr Tommy Osterberg. 


\section{University Library}

\section{- M M I N E R VA A gateway to Melbourne's research publications}

Minerva Access is the Institutional Repository of The University of Melbourne

Author/s:

Williamson, lan P.

Title:

Lessons from the Swedish land data bank system

Date:

$1987-12$

Citation:

Williamson, I. P. (1987). Lessons from the Swedish land data bank system. The Australian Surveyor, 33(8), 740-750.

Publication Status:

Published

Persistent Link:

http://hdl.handle.net/11343/34028 